\title{
Usefulness of a mobile application in undergraduate critical care teaching
}

\author{
C Leung ${ }^{*}$, G Joynt, WT Wong, C Gomersall \\ From ESICM LIVES 2015 \\ Berlin, Germany. 3-7 October 2015
}

\section{Introduction}

Very BASIC (VB) is a course for basic assessment and support of critically ill patients that is part of the curriculum for our final year medical school. In 2013, a new digital application for electronic handheld devices was introduced. It was designed to provide quick references and consisted of 57 topics presented in 38 PDF and 2 MP3, 8 flowcharts and 8 medical calculators.

\section{Objectives}

To assess the usefulness of the application in teaching critical care medicine. We hypothesize that students will find it useful and will use it during and beyond the course.

\section{Methods}

Final year medical students were offered access and encouraged to use the application during the course. The login date, time, lesson chosen were collected over 15 months then separate into 3 periods: during the 2 weeks VB course, 34 weeks post-course and 31weeks post-medical school final exam. We used questionnaire to assess students' views on its usefulness $(1=$ strong disagreement to $5=$ strong agreement). The scores of another written test taken at the end of the VB course were compared to that of 2012 students, who did not have access to the application. The application was not to be used during this $\mathrm{VB}$ test.

\section{Results}

Of the 160 (96\% of class of 166) students that used the applications, 154 (96.3\%), 121 (75.6\%), and 49 (30.6\%) logged in during the VB course, post-course and post-final exam respectively (Table 1 ). A total of 61531 logs were made. The questionnaire showed that 146 students agreed (score 4 or 5) that the application will be useful after becoming doctors; if include all users, the median (IQR) was 4(4-4.3). Overall, there was tendency to agree with positive statements and to disagree with negative statements about the usefulness of the application (Table 2) . The mean test scores for the VB course of students 2013 compared 2012 were $21.55 \pm 3.08$ and $22 \pm 4.0 \mathrm{~s}, \mathrm{p}=0.024$.

\section{Conclusions}

Our results show a high utilization rate of the application amongst students. The number of usage was highest during the course and remained high until the final examination. A third of students continued use it after graduation. Students found the application to be useful as a guide for managing critical illness and predicted continued usefulness beyond graduation. The use of the application

Table 1 Summary of application logs.

\begin{tabular}{lllll}
\hline Time period & No. of Students & No. of Logs & Mean No. of logs/student & SD \\
\hline Overall & 160 & 6531 & 41 & 35 \\
\hline During the VB Course & $154(96.3 \%)$ & 4281 & 27.8 & 24.9 \\
\hline post-course to final exam & $121(75.6 \%)$ & 1851 & 15.3 & 18.1 \\
\hline After medical school final exam & $49(30.6 \%)$ & 399 & 8.1 & 11.3 \\
\hline
\end{tabular}


Table 2 Student feedback questionnaire part 1

\begin{tabular}{|c|c|c|c|}
\hline POSITIVE STATEMENTS & $\begin{array}{l}\text { No. of } \\
\text { replies }\end{array}$ & $\begin{array}{l}\text { Median } \\
\text { Score }\end{array}$ & IQR \\
\hline It is easy to use the application to find the information that I need & 165 & 4 & $4-4$ \\
\hline The Shock audio guide is a useful concise guide to the initial management & 124 & 4 & $3-4$ \\
\hline $\begin{array}{l}\text { The guidelines provide comprehensive coverage of the important factual information required for the immediate care } \\
\text { of critically ill patients }\end{array}$ & 161 & 4 & 4-4 \\
\hline $\begin{array}{l}\text { The emergency epinephrine dosages are easily accessible and the application helped me remember the right dose } \\
\text { for different situations }\end{array}$ & 165 & 4 & $2-5$ \\
\hline The acid-base calculators helped reinforce the method for diagnosing complex acid base guidelines & 157 & 4 & $3-4$ \\
\hline The content of the application as a whole will be useful once I start working as a doctor & 164 & 4 & $\begin{array}{l}4- \\
4.3\end{array}$ \\
\hline
\end{tabular}

Table 3 Student feedback questionnaire part 2.

\begin{tabular}{|c|c|c|c|}
\hline NEGATIVE STATEMENTS & No. of replies & Median Score & IQR \\
\hline The application does not run smoothly & 165 & 2 & $2-3$ \\
\hline The GCS calculator does not reinforce the components of the score & 160 & 2 & $2-3$ \\
\hline The Acute respiratory failure audio guide is not a useful concise guide to the initial management & 129 & 2 & $2-3$ \\
\hline There are critical omissions in the guidelines & 159 & 2 & $2-3$ \\
\hline The flowcharts are unlikely to help me manage critically ill patients & 164 & 2 & $2-2$ \\
\hline The content of the application as a whole is not useful in preparing me to work as a doctor & 164 & 2 & $2-2$ \\
\hline
\end{tabular}

did not improve written test performance but also did not lead to complacency as our study shows that many students showed the initiative to use it as a learning tool beyond the course period.

Published: 1 October 2015

Cite this article as: Leung et al:: Usefulness of a mobile application in

undergraduate critical care teaching. Intensive Care Medicine Experimental 2015 3(Suppl 1):A857.

\section{Submit your manuscript to a SpringerOpen ${ }^{\circ}$ journal and benefit from:}

- Convenient online submission

- Rigorous peer review

- Immediate publication on acceptance

- Open access: articles freely available online

- High visibility within the field

- Retaining the copyright to your article 